IJOLTL, Vol. 3, No. 2, May 2018

p ISSN: 2502 2326; e ISSN: 2502 8278

Http://ijolt1.pusatbahasa.or.id; Email: ijolt1@gmail.com

Center of Language and Culture Studies, Surakarta, Indonesia

Peni, Katon Kitri. 2018. The Effectiveness of Contextual Teaching and Learning

to Teach Reading Comprehension Viewed from Students' Intelligent.

. IJOLTL (2018), 3(1): 119 132. DOI: 10.30957/ijoltl.v3i2.451.

\title{
THE EFFECTIVENESS OF CONTEXTUAL TEACHING AND LEARNING TO TEACH READING COMPREHENSION VIEWED FROM STUDENTS' INTELLIGENCE
}

\author{
Kitri Katon Peni \\ SMPN 3 Surakarta \\ Jl. Kartini No. 18, Timuran, Banjarsari, Surakarta, Indonesia \\ Email: kitrikatonpeni@gmail.com
}

\begin{abstract}
The research examines: (1) the effectiveness of Contextual teaching and learning (CTL) compared to grammar translation method in teaching reading, (2) effect of intelligence quotient to reading comprehension, and (3) interaction between teaching methods and the intelligence in teaching reading. The research was carried out at SMPN 14 Surakarta, using the experimental design assigning 72 students as sample. Data were collected using the documentary and test technique. To analyze the data, Multifactor Analysis of Variance (ANOVA) test of 2x2 and Tukey test were used. The results show that: (1) CTL was more effective than grammar translation method in teaching reading, (2) the students having high intelligence quotient had better reading comprehension than those having low intelligence, and (3) interactions occur between teaching methods and intelligence in teaching reading.
\end{abstract}

Keywords: Reading Comprehension, Contextual Teaching and Learning, Intelligence

DOI: $10.30957 /$ ijoltl.v3i2.451.

\section{INTRODUCTION}

Based on School-Based Curriculum (Kurikulum Tingkat Satuan Pendidikan) 2006 for junior high school, the aim of teaching English is to develop communicative competence. One of the four language skills that the students have to master is reading skill.

The objective of teaching reading for junior high school students is providing them with comprehending knowledge. The competence standard and the basic competence for the eighth grade want the students to be able to comprehend meaning. 
IJOLTL, Vol. 3, No. 2, May 2018

p ISSN: 2502 2326; e ISSN: 2502 8278

Http://ijolt1.pusatbahasa.or.id; Email: ijolt1@gmail.com Center of Language and Culture Studies, Surakarta, Indonesia

Peni, Katon Kitri. 2018. The Effectiveness of Contextual Teaching and Learning to Teach Reading Comprehension Viewed from Students' Intelligent.

. IJOLTL (2018), 3(1): 119 132. DOI: 10.30957/ijoltl.v3i2.451.

This meaning covers ideational, interpersonal, or textual from various interactive and monolog written texts. These texts are short functional text and genre, particularly in the form of descriptive and recount. The comprehension of reading is measured from the ability to identify words' meaning, main idea, supporting details, factual information, rhetorical steps, and purpose.

However, in reality the students of SMP 14 Surakarta still get difficulties in comprehending the English text. In addition, the students are not enthusiastic and interested in learning reading. Another factor influencing to the problem is the condition of the students that come from different social situation, creativity, intelligence and others. The fact that the teaching method is still dominated by traditional system arises some serious problems. Most students could not relate what they have learnt with the knowledge in recent and future life. It means that learning was not meaningful for students to solve the problems occurring in their lives. Learning had not been able to develop language knowledge, language skills, and language competence comprehensively. It happened because the teaching and learning process did not correlate the materials with the students' daily life, was not contextual, gave more abilities to memorize, but not to think creatively, critically, and analytically.

Therefore, the researcher is interested in conducting an experimental study by proposing a method of teaching reading comprehension, namely contextual teaching and learning (CTL). This approach assumes that learning process would be actually occurring if the students could find meaningful correlation between abstract thinking and practical application in the real context. Contextual learning is coordination between subject materials or content and intellectual skills that should be possessed by the students in a situation which is suitable with the students' cognitive psychology and environmental needs.

\section{LITERATURE REVIEW}

\subsection{Reading Comprehension Skill}

Comprehension takes place when a person is reading. It needs a set of skills that let her find the information and able to understand it. Grellet (1998:3) states that reading comprehension means extracting the required information from it as efficiently as possible. And according to Smith and Robinson (1980:54), reading comprehension is the understanding, evaluating, and utilizing of information and idea gained through an interaction between the reader and author.

Kennedy (1981:192) defines reading comprehension as a thought process through which readers become aware of an idea, understand it in terms of their experiential background and interpret it in relation to their own needs and purpose. Husein and Postlethwaithe (1994:4940-4941) state that reading comprehension is an 
IJOLTL, Vol. 3, No. 2, May 2018

p ISSN: 2502 2326; e ISSN: 2502 8278

Http://ijolt1.pusatbahasa.or.id; Email: ijolt1@gmail.com

Center of Language and Culture Studies, Surakarta, Indonesia

Peni, Katon Kitri. 2018. The Effectiveness of Contextual Teaching and Learning

to Teach Reading Comprehension Viewed from Students' Intelligent.

. IJOLTL (2018), 3(1): 119 132. DOI: 10.30957/ijoltl.v3i2.451.

extraction of certain meaning from text by the reader. It is an adaptive that is a dynamic process where the reader applies different cognitive strategies according to both their aims and the given situational context. This idea is supported by Yoakam (in Smith and Dechant, 1961:213). He says that comprehending reading matter involves the correct association of meanings with word symbols, the evaluation of meanings which are suggested in context, the selection of the correct meaning, the organization of ideas as they are read, the retention of these ideas and their use in some present or future activity.

Reading comprehension can be summarized as the act of one's mind to understand or to interpret written or printed material containing information. It involves the activity of the mind to comprehend the meaning of the text intended by the writer, to know the organization of the ideas and finally reuse it in writing or future activity. Those activities include deducing the meaning of unfamiliar lexical items, guessing the meaning of words from context, understanding explicitly stated information, distinguishing between literal and implied meanings, detecting culturally specific references, detecting such relations as main idea, and recognizing the communicative functions of written texts, according to form and purpose.

\subsection{Factors Influencing Reading}

Factors affecting reading include: (1) physical factors, (2) sociological factors, (3) psychological factors, and (4) teacher's factors. Physical deficiencies cause reading disability. Visual, auditory, speech impairments and neurological status are some physical deficiencies, which cause reading disability. Sociological factors relate to learners background. Language background depends on the extent of experience. Though the school can do much in the matter of language background and general experiences with speech and vocabulary, reading ability is a concomitant of home conditions. There is a close relation between reading and social factors. Home background can include: economic condition, opportunities for play and for social experience, nature and amount of speech and language patterns of children particularly as they are influenced by the talk of the parents, amount of reading done in the home and the availability of books, and quality of family life in terms of interparental relationships.

In the psychological factors include: interest, intelligence, reading readiness, attitude towards reading, and cognitive style. This way, intelligence is an important determinant of reading. reading is a process of thinking. Intelligence is the ability to learn and to apply what has been learned. Measures of reading comprehension tend to be more strongly correlated with intelligence than are measures for orthographic decoding (Sue, et al., 2009:1). 
IJOLTL, Vol. 3, No. 2, May 2018

p ISSN: 2502 2326; e ISSN: 2502 8278

Http://ijolt1.pusatbahasa.or.id; Email: ijolt1@gmail.com

Center of Language and Culture Studies, Surakarta, Indonesia

Peni, Katon Kitri. 2018. The Effectiveness of Contextual Teaching and Learning

to Teach Reading Comprehension Viewed from Students' Intelligent.

. IJOLTL (2018), 3(1): 119 132. DOI: 10.30957/ijoltl.v3i2.451.

Teacher related factors are the fourth that affect reading comprehension. Sometimes the teachers' professionalism and the teaching method used by them influence the reading skill of the students. In Grammar Translation Method (GTM), while teaching the text book the teacher translates every word, phrase from English into the mother tongue of learners. Further, students are required to translate sentences from their mother tongue into English. These exercises in translation are based on various items covering the grammar of the target language. The method emphasizes the study of grammar through deduction that is through the study of the rules of grammar.

\subsection{CTL}

Contextual teaching and learning is defined as a conception of teaching and learning that helps teachers relate subject matter content to real world situations (United States Department of Education Office of Vocational and Adult Education, 2001). As an innovative instructional process, it helps students connect the content they are learning to the life contexts in which that content could be used.

CTL has seven main components. Those are constructivism, inquiry, questioning, learning community, modeling, reflection, and authentic assessment (Departemen Pendidikan Nasional, 2003:10-19): Constructivism, Inquiry, Questioning, Learning Community, Modeling, Reflection, Authentic Assessment.

CTL is characterized by the use of some learning strategies more than others. In implementing CTL in this research, the researcher will apply all components of CTL. However, the researcher will not apply all of those components in every meeting. The design of implementing CTL in teaching reading can be seen in Table 1 (Nurhadi and Senduk, 2003:31-54).

In order that the teaching procedure to be used effectively, they will be integrated with other commonly accepted good teaching practices. The use of pictures, schedule of journey, artificial media are considered effective for these strategies.

\subsection{Intelligence}

Intelligence is the general capacity to think rationally, act purposefully, and to deal effectively with the environment. They cover three elements: visual-spatial intelligence, verbal-linguistic intelligence, and logical-mathematical intelligence. Reading comprehension is a complex process involving perception, recall, reasoning, evaluating, imagining, organizing, application, and problem solving. The goal of all reading is the comprehension of meaning. Students with low IQ tend to meet problem when dealing with reading comprehension if the appropriate educational adaptations are not made. A measure of verbal intelligence was significantly more strongly 
IJOLTL, Vol. 3, No. 2, May 2018

p ISSN: 2502 2326; e ISSN: 2502 8278

Http://ijolt1.pusatbahasa.or.id; Email: 1jolt1@gmail.com Center of Language and Culture Studies, Surakarta, Indonesia

Peni, Katon Kitri. 2018. The Effectiveness of Contextual Teaching and Learning to Teach Reading Comprehension Viewed from Students' Intelligent.

. IJOLTL (2018), 3(1): 119 132. DOI: 10.30957/ijoltl.v3i2.451.

correlated with the rate of reading, single-word reading, vocabulary or word knowledge, and under- standing of what was read in a text (Sue, et al., 2009:2).

\section{METHODS}

\subsection{Approach}

This experimental research is aimed at observing whether there is an interaction between teaching methods and intelligence for teaching reading. The technique used in conducting the experiment is by comparing the experimental group which is taught by contextual teaching and learning method and the control group taught by grammar translation method. Each group is classified into two different levels of intelligence quotient: the high and the low. The research design used in the research is a 2 by 2 factorial design as seen in Table 1 .

Table 1. Research design

\begin{tabular}{|c|c|c|}
\hline \multirow{2}{*}{ Intelligence Quotient (B) } & \multicolumn{2}{|c|}{ Teaching Method (A) } \\
\cline { 2 - 3 } & $\begin{array}{c}\text { Contextual Teaching and } \\
\text { Learning }\end{array}$ & $\begin{array}{c}\text { Grammar Translation } \\
\text { Method }\end{array}$ \\
\hline High $\left(\mathrm{B}_{1}\right)$ & $\left(\mathrm{A}_{1} \mathrm{~B}_{1}\right)$ & $\left(\mathrm{A}_{2} \mathrm{~B}_{1}\right)$ \\
\hline Low $\left(\mathrm{B}_{2}\right)$ & $\left(\mathrm{A}_{1} \mathrm{~B}_{2}\right)$ & $\left(\mathrm{A}_{2} \mathrm{~B}_{2}\right)$ \\
\hline
\end{tabular}

The research design, consisting of 4 different cells, can be defined as column A for the teaching methods and column $\mathrm{B}$ for intelligence quotient. The table shows that column $A_{1}$ is Contextual Teaching and Learning method and column $A_{2}$ is Grammar Translation Method. Column B consists of $B_{1}$ for students with high intelligence quotient and $\mathrm{B}_{2}$ for students with low intelligence quotient. The intelligence ranked scores are categorized into $50 \%$ of upper group (the students having high intelligence scores) and $50 \%$ of lower group (the students having low intelligence scores) from both classes. In this research, there are 36 students for each class, either experiment or control class. That is why, there are eighteen students of the upper group and eighteen students of the lower group, for both the experiment and control class.

The population of the research is the eighth grade students of SMPN 14 Surakarta. It consists of six classes. The writer uses cluster random sampling to get the sample. The sample of the research is 80 students half of them were assigned as the experimental group and the other was the controlled group.

\subsection{Technique of Collecting the Data}

The way to get the data in a research activity is usually known as a technique of collecting data. The techniques used to get the data are documentary and test 
IJOLTL, Vol. 3, No. 2, May 2018

p ISSN: 2502 2326; e ISSN: 2502 8278

Http://ijolt1.pusatbahasa.or.id; Email: 1jolt1@gmail.com Center of Language and Culture Studies, Surakarta, Indonesia

Peni, Katon Kitri. 2018. The Effectiveness of Contextual Teaching and Learning to Teach Reading Comprehension Viewed from Students' Intelligent.

. IJOLTL (2018), 3(1): 119 132. DOI: 10.30957/ijoltl.v3i2.451.

methods. The first is used to collect the data of the students' intelligence scores. The latter will be used to know the students' ability in reading comprehension. The reading comprehension test is in the form of multiple choice tests with four options.

\subsection{Technique of Analyzing the Data}

The technique used in analyzing the data is descriptive analysis and inferential analysis. Descriptive analysis is used to know the mean, median, mode, and standard deviation of the scores of the reading test. The normality and homogeneity test are done before testing the hypothesis. Inferential analysis used is multifactor analysis of variance $2 \times 2 . \mathrm{H}_{0}$ is rejected if $\mathrm{F}_{0}$ is higher than $\mathrm{F}_{\mathrm{t}}$. If $\mathrm{H}_{0}$ is rejected the analysis is continued to know which group is better using Tukey test.

\section{RESULTS}

\subsection{Descriptive Statistics}

\section{Reading score of CTL group $\left(A_{1}\right)$}

Table 2 suggests data of $A_{1}$ showing mean 63.1, SD 12.0, the mode 59.1, the median 63.5.

Table 2. Frequency Distribution of $A_{1}$

\begin{tabular}{|ccc|c|c|c|}
\hline \multicolumn{3}{|c|}{ Class Limit } & $\mathrm{f}_{\mathrm{i}}$ & $\mathrm{X}_{\mathrm{i}}$ & $\mathrm{f}_{\mathrm{i}} \mathrm{X}_{\mathrm{i}}$ \\
\hline 40 & - & 46 & 5 & 43 & 215 \\
47 & - & 53 & 3 & 50 & 150 \\
54 & - & 60 & 7 & 57 & 399 \\
61 & - & 67 & 6 & 64 & 384 \\
68 & - & 74 & 8 & 71 & 568 \\
75 & - & 83 & 7 & 79 & 553 \\
\hline \multicolumn{3}{|c|}{ Sum } & 36 & 364 & 2269 \\
\hline
\end{tabular}

2. Reading score of GTM $\left(A_{2}\right)$ group

Data of $\mathrm{A}_{2}$ shows the mean 60.1, SD 7.2, the mode 60.4, the median 60.4. See table 3 .

Table 3. Frequency Distribution of $\mathrm{A}_{2}$

\begin{tabular}{|ccc|c|c|c|}
\hline \multicolumn{2}{|c|}{ Class Limit } & $\mathrm{f}_{\mathrm{i}}$ & $\mathrm{X}_{\mathrm{i}}$ & $\mathrm{f}_{\mathrm{i}} \mathrm{X}_{\mathrm{i}}$ \\
\hline 43 & - & 47 & 2 & 45 & 90 \\
48 & - & 52 & 4 & 50 & 200 \\
53 & - & 57 & 5 & 55 & 275 \\
58 & - & 62 & 12 & 60 & 720 \\
63 & - & 67 & 7 & 65 & 455 \\
\hline
\end{tabular}


IJOLTL, Vol. 3, No. 2, May 2018

p ISSN: 2502 2326; e ISSN: 2502 8278

Http://ijolt1.pusatbahasa.or.id; Email: 1jolt1@gmail.com Center of Language and Culture Studies, Surakarta, Indonesia

Peni, Katon Kitri. 2018. The Effectiveness of Contextual Teaching and Learning to Teach Reading Comprehension Viewed from Students' Intelligent.

. IJOLTL (2018), 3(1): 119 132. DOI: 10.30957/ijoltl.v3i2.451.

\begin{tabular}{|c|c|c|c|c|}
\hline 68 & 73 & 6 & 71 & 423 \\
\hline & Sum & 36 & 346 & 2163 \\
\hline
\end{tabular}

\section{Reading score of high intelligence group $\left(B_{1}\right)$}

Data $\mathrm{B}_{1}$ shows the mean 63.1, SD 12.6, mode is 74.7, and the median 67.9. See table 4.

Table 4. Frequency Distribution of $\mathrm{B}_{1}$

\begin{tabular}{|ccc|c|c|c|}
\hline \multicolumn{2}{|c|}{ Class Limit } & $\mathrm{f}_{\mathrm{i}}$ & $\mathrm{X}_{\mathrm{i}}$ & $\mathrm{f}_{\mathrm{i}} \mathrm{X}_{\mathrm{i}}$ \\
\hline 40 & - & 47 & 5 & 44 & 218 \\
48 & - & 55 & 7 & 52 & 361 \\
56 & - & 63 & 6 & 60 & 357 \\
64 & - & 71 & 5 & 68 & 338 \\
72 & - & 79 & 11 & 76 & 831 \\
80 & - & 87 & 2 & 84 & 167 \\
\hline \multicolumn{3}{|c|}{ Sum } & 36 & 381 & 2270 \\
\hline
\end{tabular}

4. Reading scores of low intelligence group $\left(B_{2}\right)$

Data of $\mathrm{B}_{2}$ refer to mean 56.3, SD 8.3, mode 59.5, median 57.5. See table 5 .

Table 5. Frequency Distribution of $\mathrm{B}_{2}$

\begin{tabular}{|ccc|c|c|c|}
\hline \multicolumn{3}{|c|}{ Class Limit } & $\mathrm{f}_{\mathrm{i}}$ & $\mathrm{X}_{\mathrm{i}}$ & $\mathrm{f}_{\mathrm{i}} \mathrm{X}_{\mathrm{i}}$ \\
\hline 40 & - & 45 & 5 & 43 & 213 \\
46 & - & 51 & 5 & 49 & 243 \\
52 & - & 57 & 8 & 55 & 436 \\
58 & - & 63 & 12 & 61 & 726 \\
64 & - & 69 & 4 & 67 & 266 \\
70 & - & 75 & 2 & 73 & 145 \\
\hline \multicolumn{3}{|c|}{ Sum } & 36 & 345 & 2028 \\
\hline
\end{tabular}

5. Reading scores of high intelligence group taught using CTL $\left(A_{1} B_{1}\right)$

Descriptive analysis of the data of $\mathrm{A}_{1} \mathrm{~B}_{1}$ shows the mean is 74.9, SD 73.5, the median 75.5 as seen in table 6 . 
IJOLTL, Vol. 3, No. 2, May 2018

p ISSN: 2502 2326; e ISSN: 2502 8278

Http://ijolt1.pusatbahasa.or.id; Email: ijolt1@gmail.com Center of Language and Culture Studies, Surakarta, Indonesia

Peni, Katon Kitri. 2018. The Effectiveness of Contextual Teaching and Learning to Teach Reading Comprehension Viewed from Students' Intelligent.

. IJOLTL (2018), 3(1): 119 132. DOI: 10.30957/ijoltl.v3i2.451.

Table 6. Frequency Distribution of $\mathrm{A}_{1} \mathrm{~B}_{1}$

\begin{tabular}{|ccc|c|c|c|}
\hline \multicolumn{3}{|c|}{ Class Limit } & $\mathrm{f}_{\mathrm{i}}$ & $\mathrm{X}_{\mathrm{i}}$ & $\mathrm{f}_{\mathrm{i}} \mathrm{X}_{\mathrm{i}}$ \\
\hline 68 & - & 70 & 3 & 69.00 & 207.0 \\
71 & - & 73 & 4 & 72.00 & 288.0 \\
74 & - & 76 & 4 & 75.00 & 300.0 \\
77 & - & 79 & 5 & 78.00 & 390.0 \\
80 & - & 83 & 2 & 81.50 & 163.0 \\
\hline \multicolumn{3}{|c|}{ Sum } & 18 & 375.50 & 1348.0 \\
\hline
\end{tabular}

\section{Reading scores of low intelligence group taught using CTL $\left(A_{1} B_{2}\right)$}

Descriptive analysis of the data of $\mathrm{A}_{1} \mathrm{~B}_{2}$ shows the mean 51.7, SD 6.5, the mode 52.8, the median 50.8. See table 7 .

Table 7. Frequency Distribution of $\mathrm{A}_{1} \mathrm{~B}_{2}$

\begin{tabular}{|ccc|c|c|c|}
\hline \multicolumn{2}{|c|}{ Class Limit } & $\mathrm{f}_{\mathrm{i}}$ & $\mathrm{X}_{\mathrm{i}}$ & $\mathrm{f}_{\mathrm{i}} \mathrm{X}_{\mathrm{i}}$ \\
\hline 40 & - & 44 & 2 & 42 & 84 \\
45 & - & 49 & 6 & 47 & 282 \\
50 & - & 54 & 4 & 52 & 208 \\
55 & - & 59 & 3 & 57 & 171 \\
60 & - & 64 & 3 & 62 & 186 \\
\hline \multicolumn{3}{|r|}{ Sum } & 18 & 260 & 931 \\
\hline
\end{tabular}

\section{Reading scores of high intelligence group taught using GTM Method $\left(A_{2} B_{1}\right)$}

Descriptive analysis of the data of $\mathrm{A}_{2} \mathrm{~B}_{1}$ shows that the score is 43 up to 70 . The mean is 56.5 , SD 7.2, the mode 57.2, the median 56.8. The frequency distribution of the data of $\mathrm{A}_{2} \mathrm{~B}_{1}$ is in table 8 .

Table 8. Frequency Distribution of $\mathrm{A}_{2} \mathrm{~B}_{1}$

\begin{tabular}{|ccc|c|c|c|}
\hline \multicolumn{3}{|c|}{ Class Limit } & $\mathrm{f}_{\mathrm{i}}$ & $\mathrm{X}_{\mathrm{i}}$ & $\mathrm{f}_{\mathrm{i}} \mathrm{X}_{\mathrm{i}}$ \\
\hline 43 & - & 48 & 3 & 45.50 & 136.5 \\
49 & - & 54 & 3 & 51.50 & 154.5 \\
55 & - & 60 & 8 & 57.50 & 460.0 \\
61 & - & 66 & 2 & 63.50 & 127.0 \\
67 & - & 72 & 2 & 69.50 & 139.0 \\
\hline \multicolumn{3}{|c|}{ Sum } & 18 & 287.50 & 1017.0 \\
\hline
\end{tabular}


IJOLTL, Vol. 3, No. 2, May 2018

p ISSN: 2502 2326; e ISSN: 2502 8278

Http://ijolt1.pusatbahasa.or.id; Email: 1jolt1@gmail.com Center of Language and Culture Studies, Surakarta, Indonesia

Peni, Katon Kitri. 2018. The Effectiveness of Contextual Teaching and Learning to Teach Reading Comprehension Viewed from Students' Intelligent.

. IJOLTL (2018), 3(1): 119 132. DOI: 10.30957/ijoltl.v3i2.451.

\section{Reading scores of low intelligence group taught using GTM $\left(\mathrm{A}_{2} \mathrm{~B}_{2}\right)$}

Data of $\mathrm{A}_{2} \mathrm{~B}_{2}$ shows the mean 62, SD 5.9, the mode 62, the median 62. See table 9 .

Table 9. Frequency Distribution of $\mathrm{A}_{2} \mathrm{~B}_{2}$

\begin{tabular}{|c|c|c|c|c|}
\hline \multicolumn{2}{|c|}{ Class Limit } & $f_{i}$ & $X_{i}$ & $\mathrm{f}_{\mathrm{i}} \mathrm{X}_{\mathrm{i}}$ \\
\hline 50 & 54 & 2 & 52 & 104 \\
\hline 55 & 59 & 4 & 57 & 228 \\
\hline 60 & 64 & 6 & 62 & 372 \\
\hline 65 & 69 & 4 & 67 & 268 \\
\hline 70 & 74 & 2 & 72 & 144 \\
\hline \multicolumn{2}{|c|}{ Sum } & 18 & 310 & 1116 \\
\hline
\end{tabular}

\subsection{Hypothesis Testing}

Hypothesis testing is released after the test of normality and homogeneity, using multifactor analysis of variance $2 \times 2$. The results apply as: $H_{o}$ is rejected if $F_{o}$ $>\mathrm{F}_{\mathrm{t}}$ showing a difference and an interaction, if $\mathrm{H}_{\mathrm{o}}$ is rejected the analysis is continued to know which group is better using Tukey test.

Table 10 indicates the summary of a 2 x 2 Multifactor Analysis of Variance

Table 10. Multifactor Analysis of Variance

\begin{tabular}{|l|r|c|r|r|r|}
\hline \multicolumn{1}{|c|}{ Source of Variance } & \multicolumn{1}{c|}{ SS } & Df & \multicolumn{1}{c|}{ MS } & $\mathrm{F}_{\mathrm{o}}$ & $\mathrm{F}_{\mathrm{t} 0,05}$ \\
\hline Between columns & 284.014 & 1 & 284.014 & 7.38 & 4.00 \\
\hline Between rows & 1596.125 & 1 & 1596.125 & 41.47 & 4.00 \\
\hline $\begin{array}{l}\text { Columns by rows } \\
\text { (interaction) }\end{array}$ & 3916.125 & 1 & 3916.125 & 101.75 & 4.00 \\
\hline Between groups & 5796.264 & 3 & 1932.088 & - & - \\
\hline Within group & 2617.056 & 68 & 38.486 & - & - \\
\hline Total & 8413.319 & 71 & - & - & - \\
\hline
\end{tabular}

Analysis using ANOVA as in Table 9 suggests:

1) Methods of teaching differ significantly from one another in their effect on the reading comprehension of the subject in the experiment.

2) Students having high intelligence and those having low intelligence are significantly different in their reading comprehension. 
IJOLTL, Vol. 3, No. 2, May 2018

p ISSN: 2502 2326; e ISSN: 2502 8278

Http://ijolt1.pusatbahasa.or.id; Email: ijolt1@gmail.com Center of Language and Culture Studies, Surakarta, Indonesia

Peni, Katon Kitri. 2018. The Effectiveness of Contextual Teaching and Learning to Teach Reading Comprehension Viewed from Students' Intelligent. . IJOLTL (2018), 3(1): 119 132. DOI: 10.30957/ijoltl.v3i2.451.

3) There is interaction between the two variables, teaching methods and intelligence, meaning the effect of teaching methods depends on the degree of intelligence to teach reading.

The Tukey test significantly reveals:

1) Columns $\left(\mathrm{q}_{\mathrm{A}}\right)=3.84$ is higher than $\mathrm{q}_{\mathrm{t}}$ at $(\alpha)=0.05$ (2.86). It means CTL differs significantly from GTM for teaching reading. CTM is more effective to teach reading than GTM.

2) Rows $\left(q_{B}\right)=9.11$ is higher than $q_{t}$ at $(\alpha)=0.05(2.86)$, meaning students having high intelligence differs significantly from the students having low intelligence. High intelligence students have better reading comprehension than low intelligence ones.

3) Cells $A_{1} B_{1}$ and $A_{2} B_{1}=12.8$ is higher than $q_{t}$ at $(\alpha)=0.05$ (2.97). CTL differs significantly from GTM for high intelligence students. CTL is more effective than GTM for high intelligence students.

4) Cells $\left(q_{L I}\right)=3.65$ is higher than $q_{t}$ at $(\alpha)=0.05$ (2.97). GTM differs significantly from CTL for low intelligence students. GTM is more effective than CTL for low intelligence. students

5) The evident shows that CTL is more effective than GTM for high intelligence students, and GTM is more effective low intelligence students. This means an interaction occurs between teaching methods and students' intelligence in teaching reading.

\section{DISCUSSION}

\subsection{The Effectiveness of CTL}

CTL is better than GTM in variety of cases. Our findings show that CTL in reading gives opportunities for students to understand the passage through the real experience. The students learn better if the situation around them is created naturally, experience what they learn. Creating a setting in which students learn as realistically as possible is a goal of CTL (Nurhadi and Senduk, 2003:34).

Students are taught using CTL will have critical and creative thinking through searching, observing, investigating, and analyzing (Nurhadi and Senduk, 2003:43). The use of inquiry in the reading activity needs the students' involvement to find answers themselves and ask the questions along the way. The students view themselves as learners in the process of learning and they look forward to learning. 
IJOLTL, Vol. 3, No. 2, May 2018

p ISSN: 2502 2326; e ISSN: 2502 8278

Http://ijolt1.pusatbahasa.or.id; Email: ijolt1@gmail.com

Center of Language and Culture Studies, Surakarta, Indonesia

Peni, Katon Kitri. 2018. The Effectiveness of Contextual Teaching and Learning

to Teach Reading Comprehension Viewed from Students' Intelligent.

. IJOLTL (2018), 3(1): 119 132. DOI: 10.30957/ijoltl.v3i2.451.

They exhibit curiosity and ponder observation. They ask questions and use the questions to lead them to activities generating further questions or ideas. By presenting variety of different types of texts, they search who are the participants, what they do, where, when, and how they do that, the events, the complication, the resolution, and the code. After that they observe, investigate and finally analyze them.

Questioning used by the teacher can check the students' understanding, encourage students' responses, and know what the students have known make the students confident to express their answers. Students that work in a small group have the opportunities to ask questions freely among the members. Even the students who are shy to ask questions to the teacher are motivated to study together with their friends (Nurhadi and Senduk, 2003:47). The implementation of learning community really provides students more time to share their ideas or knowledge to each other. Wehrli (2003:4) says learning community is beneficial to actively involve and stimulate peer group learning, and facilitates exchange of ideas and awareness of mutual concerns and develops leadership, teamwork, communication, and collaboration skills.

Then, modeling by the teacher or the students improves the students' performance. Drawing from teacher questions or friends answers, students imitate like what they did, and have self-confidence to present or retell what they have learned in front of the class (Nurhadi and Senduk, 2003:49). Wehrli (2003:4) states role modeling is intentional teaching strategy in which learners listen and observe role model performing regular duties of the profession and/or "thinking out loud". The role modeling is powerful learning and generate high learner interest.

Reflection in CTL gives great contribution to improve students' reading comprehension. Ahmad (2006:2) states that reflection is not just an individual, psychological process. It is an action oriented, historically embedded, social and political frame, to locate oneself in the history of a situation, to participate in a social activity, and to take sides on issues. Therefore, a reading development program according to Ahmad (2006:2) should be to enable students to enjoy (or at least feel comfortable with) reading in the foreign language, and to read without help unfamiliar authentic texts, at appropriate speed, silently and with adequate understanding.

Teaching learning process needs feedback (Amin, et al., 2007:3) in terms of formative and summative assessment. Both assessments promote the feedback and can encourage students motivation to learn. CTL requires feedback to improve students interests and progress.

On the other hand, GTM is unnatural method. The natural order of learning a language is listening, speaking, reading and writing. That is the way how the child learns his language in natural surroundings, but in Grammar Translation Method the 
IJOLTL, Vol. 3, No. 2, May 2018

p ISSN: 2502 2326; e ISSN: 2502 8278

Http://ijolt1.pusatbahasa.or.id; Email: ijolt1@gmail.com

Center of Language and Culture Studies, Surakarta, Indonesia

Peni, Katon Kitri. 2018. The Effectiveness of Contextual Teaching and Learning

to Teach Reading Comprehension Viewed from Students' Intelligent.

. IJOLTL (2018), 3(1): 119 132. DOI: 10.30957/ijoltl.v3i2.451.

teaching of language starts with the teaching of reading. So, speech is neglected, consequently the students feel shy of communicating through English.

GTM attempts to teach language through rules and not by use. In fact, researchers in linguistics have proved that to speak any language, whether native or foreign, entirely by rule is quite impossible. Language learning means acquiring certain skills, which can be learned through practice and not by just memorizing rules. The students who have learned a foreign or second language through this method find it difficult to get proficiency in the second language approximating that in the first language.

\subsection{Effect of Intelligence}

Intelligence is one key to be successful in learning. Our findings show that students with high intelligence will solve the problem of learning without difficulty. High intelligence toward the method of learning strongly affects the success of learning reading and surely can affect the student's reading comprehension. Students with high intelligence have high curiosity, full of self confidence, responsible to the learning assignment, autonomous, and hard effort to attain a higher competence, and always enjoy in learning process. By high intelligence, students have hard effort optimally to achieve the success. Intelligence encompasses the ability to create and solve problems, create products or provide services that are valued within a culture or society (Gardner, 1999:41-43).

On contrary, students with low intelligence are passive recipient of knowledge. They rely on teachers' feeding, don't try hard, give up easily in the face of challenge, and do not have desire to improve their competencies. The students are discouraged to involve in doing learning activities, lazy to learn, get bored easily, and they do not feel pleasure in classroom. They have less capacity to learn and carry on abstract thinking. Low intelligence is the cause of reading disability when appropriate educational adaptations are not made.

\subsection{Interaction between teaching methods and students' intelligence.}

Success of learning includes not only the teaching methods but also the students' intelligence. Our findings show interactions between teaching method and intelligent do occur. Participation and involvement in learning activities is strongly affected by the teaching method. GTM cannot motivate the students because it is teacher-centered; the teacher is regarded as the source of knowledge. CTL is studentcentered that should actively participate in learning activities.

CTL gives opportunities for the students to understand the passage through the real experience. The students find the type of the text by searching who are the participants, what they do, where, and how they do that, and the like. Then if they 
IJOLTL, Vol. 3, No. 2, May 2018

p ISSN: 2502 2326; e ISSN: 2502 8278

Http://ijolt1.pusatbahasa.or.id; Email: ijolt1@gmail.com

Center of Language and Culture Studies, Surakarta, Indonesia

Peni, Katon Kitri. 2018. The Effectiveness of Contextual Teaching and Learning

to Teach Reading Comprehension Viewed from Students' Intelligent.

. IJOLTL (2018), 3(1): 119 132. DOI: 10.30957/ijoltl.v3i2.451.

find difficulties they can express their questions to the teacher or their friends in a small group. They can also make model from the teacher or their friends in answering the questions of the text (Nurhadi and Senduk, 2003:34-51).

The students having high intelligence have high curiosity, self confidence are responsible for the learning assignment, autonomous and effort to attain a higher competence. Gardner (1999:41-43) states that intelligence encompasses the ability to create and solve problems, create products or provide services that are valued within a culture or society. Therefore, when they are taught using contextual teaching and learning they understand the passage easily; they have creative thinking and do the assignment better. The students do not depend on the teacher's translation and explanation. They try to find the meaning and the message from the text by themselves or they will ask friends that work in a small group.

Nurhadi and Senduk (2003:47-51) said that questioning and modeling used by their friends or their teacher can improve the students' performance. Finally, students are free to join the class. The students who have high intelligence have high ability in comprehending the various text types. Fathi, et al., (2009:12) advocate the multiple intelligence program was effective in improving the reading comprehension skills, compared to individuals taught conventionally. CTL, therefore, is more effective for the students having high intelligence in teaching reading comprehension.

GTM starts with the teaching of reading. It is unnatural order. The natural one is listening, speaking, reading, and writing. Then translation is the easiest way of explaining meanings or words and phrases from one language into another. Since the passages are also taught through the medium of the mother tongue, the teacher may ask comprehension questions on the text taught in the mother tongue.

In learning the EFL students having low intelligence prefer reading to listening. They are also passive recipient of knowledge, depend on the teacher's explanation to read the text, do not have initiative, and wait for the teacher's translation on the text. Here, GTM makes them active, listen carefully to the teacher's explanation to read the text and enjoy the teacher's translation to know the meaning and the message of the text. They become enthusiastically in learning process because they can respond questions in the mother tongue. Even, they can communicate with the teachers without linguistic problems. Finally, they do not get difficulty in doing the assignment. This way, GTM is more effective for the students having low intelligence for teaching reading comprehension.

There is an interaction between teaching methods and students' intelligence in teaching reading comprehension. CTL is suitable for students having high intelligence and GTM is for students having low intelligence. 
IJOLTL, Vol. 3, No. 2, May 2018

p ISSN: 2502 2326; e ISSN: 2502 8278

Http://ijolt1.pusatbahasa.or.id; Email: ijolt1@gmail.com Center of Language and Culture Studies, Surakarta, Indonesia

Peni, Katon Kitri. 2018. The Effectiveness of Contextual Teaching and Learning to Teach Reading Comprehension Viewed from Students' Intelligent. . IJOLTL (2018), 3(1): 119 132. DOI: 10.30957/ijoltl.v3i2.451.

\section{CONCLUSION AND IMPLICATION}

In summary, this study contributes three finding. In general, CTL is evidently more effective than Grammar Translation Method to teach reading comprehension. Specifically, students having high intelligence have better reading comprehension than those having low intelligence. In addition, there is an interaction between teaching methods and students' intelligence in teaching reading comprehension. In other words, the effectiveness of the method is influenced by the students' level of intelligence.

This study is by no means perfect showing limitation in the sample selection and the number of respondent. Sample is in restriction because two classes of students were assigned at random. This implies that the results look like to be designed addressing that CTL performs better than GTM and students involved in the CTL inhibit the controlled group taught using GTM. More specifically, interactions between higher intelligent and teaching methods have occurred in the experimental group where CTL have been applied. Future research is suggested to expand the number of sample up to 100 students involving more heterogeneous students and observe intelligent in both experimental and controlled groups.

\section{REFERENCES}

Ahmad, Zakia. 2006. Reflection and the Teaching of Reading. Available at nepjol.info/nepal/index.php/NELTA/article/download/3129/2730 Accessed on June 9, 2011

Departemen Pendidikan Nasional Direktorat Jenderal Pendidikan Dasar dan Menengah. 2003. Pendekatan Kontekstual, Jakarta

Grellet, Francoise. 1998. Developing Reading Skills. Cambridge: Cambridge University Press.

Husein, Torsten and Postlehwaite T. Neville. 1994. The International Encyclopedia of Education vol. 8. London: BPC Wheaton Ltd.

Kennedy, Eddie C. 1981. Methods in Teaching Developmental Reading (second edition). Itasca: F. E. Peacock Publisher, Inc.

Nurhadi \& Senduk, A. G. 2003. Pembelajaran Kontekstual dan Penerapannya dalam $K B K$. Malang: Penerbit Universitas Negeri Malang

Smith, Nila B and Robinson, H Alan. 1980. Reading Instruction for Today's Children. Englewood Cliffs: Prentice Hall, Inc.

United States Department of Education Office of Vocational and Adult Education, 2001

Wehrli, G. and Nyuquist, J.G. 2003. Teaching Strategies/Methodologies. Available at http;hsc.unm.edu/som/ted/TEACHING\%20 STRATEGIES .pdf 